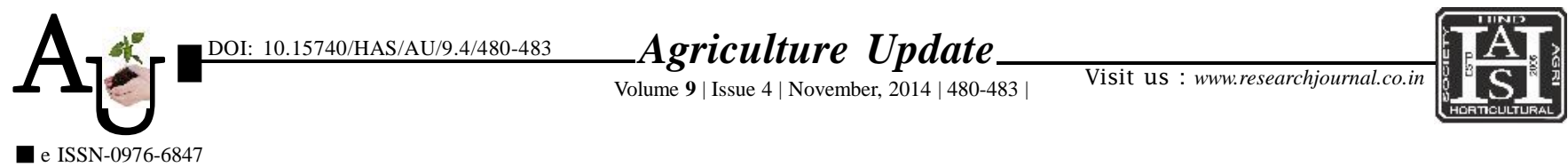

\title{
Research Article Information seeking behaviour of the rice growers
}

\author{
口 VISHVAJEET J. PATEL AND N.M. CHAUAHAN
}

Article Chronicle:

Received :

26.07.2014;

Revised :

27.08.2014;

Accepted :

11.09.2014

\section{KEY WORDS:}

Information

seeking,

Behaviour,

Rice growers
SUMMARY : The present investigation was confined to Navsari district of South Gujarat. The information need of the 100 rice growers was measured using three point continuums. Major area of information needs expressed by the rice growers in descending order of rank were schedule of water supply by canal, weed management, marketing, irrigation management, variety, preparation of seedlings, plant protection measures, land preparation and sowing, fertilizer management, harvesting and post harvesting technology and supportive facts. This means that the rice growers gave highest emphasis on schedule of water to be supplied by canal related information, as this, information can help them to make a great management on schedule of water to be suppled by canal. They were also conscious about information on weed management as well as marketing and many other aspects of paddy. They articulated high need for information on market price followed by quality parameters that affects price and time of market inflow. It can be seen that the rice growers expressed their needs for information about subsidies, insurance and government policies related to rice cultivation. It was also observed from this study that five variables viz., use of information sources, extension participation, land under rice cultivation and cosmopoliteness were observed positive and significantly related with the information needs of the paddy growers. Age, education, social participation, size of land holding, irrigated area to total land, annual income, economic motivation and market orientation was observed positively and non-significantly related with the information needs of the paddy growers.

How to cite this article : Patel, Vishvajeet J. and Chauahan, N.M. (2014). Information seeking behaviour of the rice growers. Agric. Update, 9(4): 480-483.
Author for correspondence :

\section{N.M. CHAUHAN}

Krishi Vigyan Kendra, (NAU), TAPI (GUJARAT) INDIA

Email: nikulsinh_m@ yahoo.in

See end of the article for authors' affiliations 